\title{
PELESTARIAN NILAI-NILAI BUDAYA PADA KESENIAN KUDA LUMPING DI KECAMATAN TAMBUSAI UTARA
}

IlHam RahmaWati, Ryan Prayogi

Received: 29 Juni 2021; Accepted: 20 Agustus 2021; Published: 28 September 2021

Ed. 2021; 5 (1): 01 - 06

\begin{abstract}
This research is based on cultural issues. The aims of this research are (1) How to describe the preservation of cultural values in Kuda Lumping art in North Tambusai District. This research is a qualitative research with ethnographic method. The sampling technique in this research is using a proposive sampling technique-nonprobalistic. Data analysis techniques used in this research are data reduction, data presentation, and conclusion drawing. The results of the study show that in Kuda Lumping art there are cultural values that can be used as guidelines and references in people's lives including religious values, mutual cooperation values, responsibility values, unity values, ethical values, solidarity values (togetherness), and aesthetic values. (beauty).
\end{abstract}

Keywords: Preservation, Value, Lumping Horse.

\section{PENDAHULUAN}

Indonesia merupakan negara yang berasal dari beraneka ragam suku bangsa. Disetiap suku bangsanya memiliki keanekaragaman budaya atau cultural diversity. Keanekaragaman budaya di Indonesia disebabkan oleh beberapa faktor diantaranya faktor geografis, agama, politik, ekonomi, dan berbagai hal lainnya yang mampu memperkaya kebudayaan di Indonesia. Dalam Undang-undang Nomor 5 Tahun 2007 kebudayaanadalahsegalasesuatuyangberkaitan dengan cipta, karsa, dan hasil karya masyarakat.

Kesenian sebagai salah satu hasil aktivitas masyarakat yang dalam perkembangannya tidak dapat berdiri sendiri. Sebagai pendukungnya hampir di setiap daerah memiliki latar belakang sejarah dan kondisi sosial yang berbeda- beda. Dengan adanya latar belakang sejarah serta kondisi sosial yang berbeda tersebut mampu memberikan ciri khusus yang membedakan antara kesenian yang ada di satu daerah dengan daerah yang lainnya.
Kesenian Kuda Lumping yang berada di kecamatan Tambusai Utara merupakan salah satu kesenian tradisional yang berkembang secara turun temurun dari satu generasi ke generasi berikutnya. Dewasa saat ini, masyarakat di kecamatan Tambusai Utara sangat terhibur ketika kesenian Kuda Lumping melakukan pertunjukan. Hal tersebut dapat dilihat dari tingginya antusias masyarakat setempat yang ikut menyaksikan jalannya pertunjukan. Namun pada saat sekarang masyarakat enggan bergabung sebagai anggota dari kesenian kuda lumping tersebut sehinnga para pemain sudah mulai berkurang.

Berdasarkan hasil observasi awal permasalahan dalam penelitian ini adalah: Pertama banyak masyarakat yang belum memahami nilai-nilai tradisi yang terdapat pada kesenian Kuda Lumping. Permasalahan kedua adalah banyaknya generasi muda yang memilih untuk bekerja keluar daerah. Hal ini menjadi 
salah satu faktor yang mampu mempengaruhi upaya pelestarian kesenian Kuda Lumping. Permasalah ketiga adalah tidak semua kalangan masyarakat mempunyai minat untuk menyaksikan pertujukan kesenian Kuda Lumping. Hal tersebut dikarenakan adanya anggapan bahwa kesenian Kuda Lumping merupakan kesenian tradisional yang sudah tidak eksis lagi. Permasalahan yang keempat adalah adanya anggapan bahwa kesenian Kuda Lumping yang masih mempertunjukkan unsur-unsur magis dengan berbagai sesaji yang bertujuan untuk memanggil roh leluhur dianggap sebagai kegiatan yang tidak sesuai nilai-nilai agama islam

Latar belakang masalah diatas memaparkan bahwa pelestarian nilai-nilai budaya pada tradisi kesenian Kuda Lumping dianggap sangat penting karena selain sebagai sara ritual, hiburan, pendidikan, dan penanaman identitas bangsa. Kemudian kesenian Kuda Lumping juga memiliki berbagai manfaat dan nilai-nilai tradisi yang penting untuk dipelajari. Tumbuh kembangnya kesenian Kuda Lumping di Kecamatan Tambusai Utara dapat dijadikan sebagai aset dan ciri khas yang membedakan antara kesenian yang ada di setiap Kecamatan yang berada di Kabupaten Rokan hulu, Riau.

Kebudayaan merupakan seluruh cara kehidupan dari masyarakat yang terdapat diberbagai aspek kehidupan diantaranya cara berprilaku, kepercayaan yang dianut, sikap yang digunakan dalam berinteraksi, serta sebagai ciri khas suatu masyarakat atau kelompok-kelompok penduduk tertentu. (TRIYANTO, 2018:67), mengatakan bahwa kebudayaan dan manusia merupakan dua hal yang tidak dapat dipisahkan hal ini bisa dilihat dari keberadaan manusia yang selalu menghasilkan kebudayaan, begitu juga sebaliknya kebudayaan tidak akan lahir tanpa adanya manusia.

(SuMARYONO, 2016: 196), berpendapat bahwa kesenian Kuda Lumping merupakan salah satu jenis kesenian yang hidup serta tumbuh dan berkembang pada masyarakat pedesaan. (KEMUDIAN WinARSIH, 2008: 11), menyatakan bahwa Kuda Lumping adalah seni tari yang dimainkan dengan menaiki kuda tiruan darianyaman bambu (kepang). Dalam memainkannya biasanya diiringi dengan musik khusus yang sederhana karena hanya permainan rakyat yaitu dengan gong, kenong, khendang, dan selompret. Dengan demikian dapat dikatakan bahwa kesenian Kuda Lumping adalah kesenian yang dalam pertunjukannya menggunakan properti dari anyaman bambu. Hal ini sejalan dengan istilah bahasa Jawa yang mengatakan bahwa kesenian Kuda Lumping disebut juga sebagai kesenian jaran kepang, hal ini disebabkan karena tarian ini menggunakan alat peraga berupa jaranan (kuda-kudaan) yang bahannya dibuat dari kepang (bambu yang dianyam) sehingga dapat diartikan sebagai pertunjukan dengan kuda-kudaan yang dianyam dari anyaman bambu atau kulit bambu.

\section{METODE PENELITIAN}

Berdasarkan kajian masalah serta fokus penelitian tentang upaya pelestarian nilai-nilai budaya pada tradisi kesenian Kuda Lumping di Kecamatan Tambusai Utara Kabupaten Rokan Hulu maka penelitian ini menggunakan pendekatan kualitatif serta menggunakan metode yang dapat digunakan untuk mencapai sasaran yang dituju sehingga penelitian ini bisa benar-benar bersifat representatif dan objektif. (Menurut Sugiyono, 2014: 1-2), metode penelitian kualitatif juga sering disebut sebagai metode penelitian naturalistik karena penelitian ini dilakukan pada kondisi yang alamiah. Natural setting disebut juga sebagai metode etnografi, karena pada awalnya metode ini lebih banyak digunakan untuk penelitian dibidang antropologi budaya. Disebut sebagai metode kualitatif, karena data yang terkumpul dan analisisnya lebih bersifat kualitatif.

Obyek dalam penelitian kualitatif adalah obyek yang alamiah atau natural setting, obyek yang alamiah adalah obyek yang apa adanya, tidak dimanipulasi oleh peneliti sehingga kondisi pada saat peneliti memasuki obyek, sebelum berada di obyek dan setelah keluar dari obyek kondisinya relatif tidak berubah. 
Alasan peneliti memilih pendekatan kualitatif yaitu: Pertama diharapkan peneliti dapat memperoleh informasi dan data yang akurat mengenai penelitian yang dilakukan. Kedua data yang akan diperoleh dari penelitian di lapangan lebih banyak menyangkut perbuatan dan ungkapan kata- kata dari responden yang sedapat mungkin bersifat alami, tanpa adanya rekayasa serta pengaruh dari luar.

Metode yang digunakan dalam penelitian ini adalah metode etnografi. Metode etnografi termasuk jenis penelitian kualitatif. Penelitian etnografi menurut (CRESWELL, 1993: 145), yakni "fokus pada masyarakat, memilih informan yang diketahui memiliki pandangan yang luas dan mendalam terhadap aktivitas masyarakat yang diteliti. Menekankan pada makna bagaimana masyarakat make sense kehidupannya, pengalaman, dan struktur dunianya sendiri”. Inti dari etnografi adalah upaya untuk memperhatikan makna-makna tindakan dari kejadian yang menimpa orang yang ingin kita pahami (Spradley, 2010: 4).

\section{PEMBAHASAN}

\section{Deskripsi Nilai-nilai Tradisi yang Terdapat dalam Kesenian Kuda Lumping.}

Kesenian Kuda Lumping Budi Utomo merupakan salah satu kesenian peninggalan nenek moyang suku Jawa yang telah diturunkan dari satu generasi ke generasi berikutnya. Di dalam kesenian Kuda Lumping Budi Utomo terdapat nilai-nilai tradisi yang meliputi nilai religi, nilai etika, nilai toleransi, nilai persatuan, nilai gotong royong, nilai tanggungjawab, nilai estetika (keindahan), dan nilai solidaritas (kebersamaan). Nilai-nilai tradisi tersebut dapat dilihat dari berbagai prosesi yang dilakukan oleh group kesenian Kuda Lumping Budi Utomo seperti kegiatan berkumpul, menyiapkan tempat pertunjukan, menyiapkan ubo rampe (sesaji), mempersiapkan alat musik, mempersiapkan para pemain, pembagian tugas sesuai dengan keahlian, dan pengrawitan. Nilai religius lainnya yang terdapat pada kesenian Kuda Lumping Budi Utomo dapat dilihat dari adanya prosesi obong menyan (membakar kemenyan). Prosesi ini dilakukan oleh seorang pawang yang diiringi dengan suara tetabuhan gamelan Kuda Lumping. Adapun tujuan dari kegiatan pembakaran kemenyan adalah sebagai bentuk penghormatan dan meminta izin kepada roh leluhur yang ada di area pertunjukan. Hal tersebut sejalan dengan hasil penelitian yang dilakukan oleh BuDi (2019) yang mengatakan bahwa prosesi pertama yang dilakukan sebelum pertunjukan kesenian Kuda Lumping dimulai adalah dengan prosesi pembakaran kemenyan yang bertujuan untuk mendatangkan roh leluhur agar senantiasa membantu dalam prosesi pertunjukan kesenian Kuda Lumping.

Selanjutnya, nilai religi yang terdapat pada kesenian Kuda Lumping adanya prosesi berdoa. Kegiatan ini diawali dengan berkumpulnya para pawang ketengah area pertunjukan untuk membacakan berbagai doa dan mantra-mantra yang sesuai dengan kepercayaan dan keyakinan yang dianut. Selanjutnya nilai yang terdapat pada kesenian Kuda Lumping adalah nilai toleransi. Nilai toleransi merupakan nilai yang menggambarkan suatu keadaan dimana disetiap para anggota harus saling menghargai dan menghormati pendapat orang lain walaupun pendapat tersebut tidak sesuai dengan apa yang diinginkan. Nilai toleransi yang terdapat pada kesenian Kuda Lumping dapat dilihat dari dibuatnya jadwal pertunjukan. Kesenian Kuda Lumping sangat memperhatikan kehidupan para anggotanya. Karena mayoritas anggota kesenian Kuda Lumping beragama islam maka waktu pertunjukan kesenia Kuda Lumping sangat memperhatikan wakhu sholat fardhu.

Nilai selanjutnya yang terdapat pada kesenian Kuda Lumping adalah nilai estetika (keindahan). Nilai tersebut dapat dilihat dari tata rias, iringan musik, kostum, serta gerak tarian para penari. Tata rias merupakan hal yang sangat penting bagi seorang penari. Tata rias yang digunakan oleh para penari kesenian Kuda Lumping bertujuan untuk menggambarkan karakter tokoh yang sedang dibawa- 
kan, untuk memperkuat ekspresi, dan untuk menambah daya tarik penampilan sehingga dapat menarik perhatian para penonton. Dengan adanya tata rias tersebut para penonton akan mudah memahami peran apa yang sedang dibawakan oleh penari sehingga para penonton dapat memahami dengan mudah cerita yang sedang dibawakan.

Nilai estetika (keindahan) lainnya dapat dilihat dari gerak tarian para penari yang memberikan kesan luwes dan lincah. Adapun gerak tarian yang ada pada kesenian Kuda Lumping adalah tarian pembuka, tarian senterewe, tarian breng, dan tarian barongan dan topeng.

Nilai selanjutnya yang terdapat pada kesenian Kuda Lumping adalah nilai solidaritas atau kebersamaan. Menurut SoEkANTO (1987: 68-69) solidaritas sosial merupakan kohesi yang ada antara anggota suatu asosiasi, kelopok, kelas, sosial, kasta, dan antara barbagai individu dan kelompok, maupun kelas-kelas membentuk masyarakat, dengan bagian-bagiannya. Nilai solidaritas atau kebersamaan dalam pertunjukan kesenian Kuda Lumping Turonggo Seto dapat dilihat dari berbagai prosesi yang dilakukan yakni proses berkumpulnya para anggota, dan prosesi mberai (berdandan).

Berkumpulnya para anggota kesenian Kuda Lumping pada saat latihan, rapat bulanan, maupun pada saat kesenian ini melakukan pertunjukan sangat berpengaruh terhadap terbentuknya kekompakan dari setiap anggotanya. Berbagai kegiatan yang dilakukan biasanya dihadiri oleh berbagai kalangan masyarakat baik anggota maupun masyarakat sekitar yang memiliki ketertarikan terhadap kesenian Kuda Lumping. Berkumpulnya masyarakat disuatu tempat memicu lahirnya suatu kebersamaan yang terbentuk karena adanya ketertarikan terhadap kesenian tradisional yakni kesennian Kuda Lumping, serta terjalinnya komunikasi yang baik antar anggota maupun antar penonton. Nilai selanjutnya yang ada pada kesenian Kuda Lumping adalah nilai persatuan. Nilai persatuan yang terdapat pada kesenian Kuda Lumping dapat dilihat dari beragamnya masyarakat yang bergabung menjadi anggota. Anggota yang bergabung kedalam group kesenian Kuda Lumping berasal dari berbagai kalangan. Mulai dari anak-anak, remaja, hingga orang dewasa bahkan masyarakat dari desa lain yang memiliki jiwa seni serta kecintaan terhadap kesenian Kuda Lumping juga ikut bergabung. Dengan bergabungnya mereka kedalam group kesenian Kuda Lumping membuat mereka saling hidup rukun dan bersatu demi terwujudnya suatu group kesenian Kuda Lumping yang moderen yang dapat bersaing dengan kesenian lainnya yang ada ditengah-tengah masyarakat pada saat ini.

Berikutnya nilai tradisi yang terdapat pada kesenian Kuda Lumping adalah nilai gotong royong. Nilai gotong royong tersebut dapat dilihat dari berbagai prosesi yang dilakukan secara bersama-sama mulai dari pembuatan tempat pertunjukan, dan menyiapkan alatalat. Tempat Pertunjukan merupakan arena penting yang digunakan dalam prosesi pertunjukan. Ada beberpa hal yang berkaitan dengan tempat pertunjukan mulai dari panggung hingga arena yang dibuat sebagai pembatas antara penonton dan penari. Panggung yang diperlukan pada pertunjukan kesenian Kuda Lumping biasanya berbentuk persegi panjang. Selain itu para anggota juga membuat tarub, tarub tersebut biasanya terbuat dari seng atau terpal dibuatnya tarub tersebut bertujuan untuk melindungi para penari dan penabuh dari sengatan sinar matahari. Selanjutnya para anggota akan membuat arena pembatas pertunjukan yakni dengan memberi pagar pada sekitar arena pertunjukan. Biasanya pagar tersebut terbuat dari bambu atau tali yang diikat pada suatu tombak atau tiang. Berbagai proses tersebut dilakukan secara bersamasama secara sukarela tanpa mengharapkanupah.

Selanjutnya adalah nilai etika nilai tersebut terdapat pada gerak tarian yang ditunjukkan oleh para penari. Ada berbagai gerak yang dimainkan oleh para penari seperti gerak persemba- 
han gerakan ini merupakan suatu gerak yang menggambarkan suatu salam penghormatan yang ditunjukkan kepada tuan rumah, tamu undangan, dan para penonton. Selain itu gerakan tanjak (kuda-kuda) menggambarkan sosok manusia yang harus memiliki pendirian yang kuat sehingga tidak dapat terkeco oleh berbagai ujian yang sedang dihadapi.

Nilai yang terakhir yang terdapat pada kesenian Kuda Lumping Turonggo Seto adalah nilai tanggungjawab. Nilai tanggung jawab tersebut dapat dilihat dari sikap dan perilaku seseorang yang melaksanakan tugas dan kewajiban terhadap diri sendiri, masyarakat, lingkungan, negara, dan Tuhan Yang Maha Esa. Nilai tanggung jawab yang ada pada kesenian Kuda Lumping terlihat pada prosesi pengrawitan. Dengan adanya pengrawitan ini para anggota akan menempati tempatnya masih-masing dan melaksanakan tugasnya secara tertib. Misalnya saja seorang penabuh mereka secara spontan sudah dapat menempati posisinya masing-masing dan langsung memainkan alat-alat yang memang sudah ditugaskan sebelumnya. Selanjutnya seorang pawang, mereka akan melaksanakan tugasnya mulai dari ngobong menyan (membakar kemenyan), berdoa, sampai menyadarkan para pemain yang sedang kesurupan.

Berdasarkan paparan di atas dapat diketahui bahwa di dalam kesenian Kuda Lumping terdapat beragam nilai-nilai tradisi. Hal tersebut senada dengan hasil penelitian yang dilakukan oleh LARAs (2019), yang mengatakan bahwa nilai yang terdapat pada kesenian Kuda Lumping adalah sebagai berikut:

"Nilai mistis dalam bentuk pertunjukan yaitu nilai kepercayaan kepada Tuban Yang Maha Esa dan nilai kepercayaan kepada rob lelubur saat melakukan semedi pada malam sura di sungai Mandhang.Nilai menghormati kepada roh disekitar pertunjukan dan nilai kebersamaan saat menyediakan sesaji.Nilai keberanian pada diri penari Kuda Lumping yang ingin melakukan pertunjukan atraksi atau intrance".
Menurut IswANDI (2012), dalam hasil penelitian yang telah dilakukannya bahwa terdapat dua unsur yang mempengaruhi performan Kuda Kepang yakni pertunjukan kesenian tradisional Kuda Kepang itu sendiri dan nilai magis yang terdapat pada kesenian Kuda Kepang tersebut. Dalam pementasannya kedua unsur tersebut tidak bisa dipisahkan karena keduanya bergabung menjadi satu kesatuan dalam sebuah pertunjukan yang saling melengkapi. Disetiap pertunjukan kesenian Kuda Kepang selalu disertai oleh unsur magis yang menjadi ciri khas dalam pertunjukan kesenian tradisional Kuda Kepang yang membuat pertunjukan kesenian memiliki nilai estetika dan nilai hiburan sehingga pertunjukan ini layak untuk ditonton. Istilah kesenian Kuda Lumping memiliki beraneka ragam nama dan sebutan yang berbeda-beda hal tersebut disesuaikan dengan adat istiadat dimana kesenian itu hidup dan berkembang. Hal tersebut sesuai dengan pendapat Claire Holt (Kuswarsantyo, 2017: 36).

\section{KESIMPULAN}

Terdapat nilai-nilai tradisi pada kesenian Kuda Lumping Budi Utomo diantaranya adalah nilai religi, nilai gotong royong, nilai etika, nilai toleransi, nilai keindahan (estetika), nilai tanggunjawab, dan nilai solidaritas (kebersamaan). Nilai-nilai tradisi tersebut dapat dilihat dari berbagai prosesi yang dilakukan oleh group kesenian Kuda Lumping mulai dari kegiatan berkumpulnya para pemain dan anggota, menyiapkan tempat pertunjukan serta merapikan alat-alat yang digunakan pada saat pertunjukan, menyiapkan ubo rampe (sesaji), membakar kemenyan, berdoa sebelum melakukan pertunjukan, berhias, dan pengrawitan.

\section{DAFTAR PUSTAKA}

AMANDA LaRAs SAKanthi

2019. Nilai Mistis pada Bentuk Pertunju kan Kesenian Kuda Lumping Satrio Wibowo di Desa Sanggrahan Kabupaten Temanggung. Jurnal Seni Tari Vol 2 no 8. 
BANGKit Rantiksa.

2017. Upaya Masyarakat dalam Melestarikan Kesenian Kuda Lumping di Dusun Tegal Temu, Kelurahan Manding, Kabupaten Temanggung. Jurnal Pendidikan sosiologi. Volume 6 no.3.

Creswell, J. W.

1993. Research design: Penelitian Kualitatif dan Kuantitatif dan Miked. Yogyakarta: Pustaka Belajar.

Fransiskus Indra Udhi Prabowo.

2015. Pelestarian Kesenian Kuda Lumping oleh Paguyuban Sumber Sari di

Desa Pandan Sari Kecamatan Sruweng Kabupaten Kebumen. Jurnal Program Studi Pendidikan Bahasa dan Sastra Jawa. Vol 6 no. 01.

Handayani, C.

2006. Bangkitnya Kembali Kesenian

Tradisional Rakyat Sebagai Warisan

Nenek. Moyang di Bukit Menoreh

Bumi Sabhara Budhara.

Harmoni Jurnal pengetahuan dan

Pemikiran Seni, Vol. III, No 02, 3.

Hasan, S. S.

2011. Pengetabuan Ci Budaya Cultural

Studi Sejarah Pendekatan Konseptual \& Isu Menuju Studi Budaya Kapitalis

Lanjut. Depok: Ar-Ruzza Media.

LUTFITA RizkY.

2018. Fenomena Malim dalam Tradisi Seni Kuda Lumping. Jurnal Budaya Etnika. vol 02 no. 01.

Miles dan Hubermen.

2007. Analisa Data Kualitatif Buku

Sumber Tentang Metode-metode Baru.

Jakarta: Universitas Indonesia Press.

Prasetyo, J. T DKK.

2009. Ilmu Budaya Dasar (Cetakan ke-3).

Jakarta: PT Rineka Cipta.
Spradley, J. P.

2010. Metode Etnografi. Yogyakarta: PT Tiara Wacana.

Sumaryono.

2016. Antropologi Tari dalam Prespektif Indonesia. Yogyakarta: Media Kreativitas.

SugIYONO.

2014. Metode Penelitian Kualitatif dan ReD (Cetakan ke-9). Bandung: Alfabeta.

TRIYANTO.

2018. Pendekatan Kebudayaan dalam Penelitian Pendidikan Seni. Vol XII No 1, 67.

WINARSIH.

2008. Mengenal Kesenian Nasional Kuda Lumping. Solo: PT Bengawan Ilmu. dst 